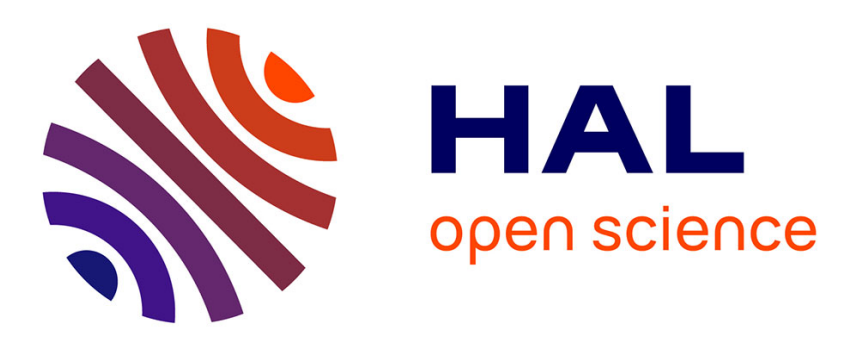

\title{
Researchers Behind Policy Development: Comparing 'Age-Friendly Cities' Models in Quebec and Wallonia
}

\author{
Thibauld Moulaert, Suzanne Garon
}

\section{To cite this version:}

Thibauld Moulaert, Suzanne Garon. Researchers Behind Policy Development: Comparing 'AgeFriendly Cities' Models in Quebec and Wallonia. Journal of Social Work Practice, 2015, 29 (1), pp.23-35. 10.1080/02650533.2014.993946 . halshs-01589620

\section{HAL Id: halshs-01589620 \\ https://shs.hal.science/halshs-01589620}

Submitted on 25 Sep 2017

HAL is a multi-disciplinary open access archive for the deposit and dissemination of scientific research documents, whether they are published or not. The documents may come from teaching and research institutions in France or abroad, or from public or private research centers.
L'archive ouverte pluridisciplinaire HAL, est destinée au dépôt et à la diffusion de documents scientifiques de niveau recherche, publiés ou non, émanant des établissements d'enseignement et de recherche français ou étrangers, des laboratoires publics ou privés. 


\section{Researchers Behind Policy Development: Comparing 'Age-Friendly Cities' Models in Quebec and Wallonia}

\section{Thibauld Moulaert \& Suzanne Garon}

\section{Abstract}

Based on a reflexive method, this article explores the roles of researchers behind AgeFriendly Cities and Environments. Referring to Michael Burawoy's division of sociological work (professional, critical, policy and public sociology), it is structured around the international comparison of two empirical case studies: Walloon region (Belgium) and Quebec (a province of Canada). While the first case shows some difficulties faced by a limited policy sociology perspective with little room for research, the latter presents a more developed public sociology approach with larger involvement from research. If both cases started with policy links, the latter presents a special interest for praxis, through knowledge transfer as an ongoing public dialogue. Based on this comparison, the article concludes with a twofold use of praxis: on one side - knowledge in action - a public sociology position offers an original perspective on what AFC/AFE may mean and produce to avoid a limited field of actions focusing only on some stakeholders or advocates for older people. On the other side - action in knowledge - policy and public sociology question professional and critical sociology facing AFC/AFE programmes: is a purely academic knowledge of such a programme epistemologically realistic or should it necessarily be empirically fuelled?

\section{Keywords}

Age-Friendly City; Age-Friendly Environment; Reflexive method; Praxis; Public sociology; Researcher/policy relation; International comparison 


\section{Introduction}

The study of Age-friendly environments (AFE) is becoming a central development for social sciences in general and for social work and social gerontology in particular. Impetus was originally given by the World Health Organization (WHO, 2007a) as a central driver to transform the idea of active ageing (WHO, 2002) into practice through the Age-friendly cities (AFCs) initiative and the WHO Global Network on Age-friendly Cities and Communities (GNAFCC). And is now being extended to discussions on AFE and Communities conceptualised as an expansion of ecological theories (Menec et al., 2011) and as the search for a new research domain defined as 'environmental gerontology' (Phillipson, 2004, 2011).

However, the place of the researcher within such developments has rarely been discussed, often being taken as something self-evident and not a matter for critical discussion. Three examples would include: First, the Vancouver Protocol (i.e. the original methodological framework to support the first steps of the AFC-programme launched by the WHO in 2006 and whose result is the final report on AFCs: the (WHO, 2007a) indicates the needs for a researcher 'to ensure that the research process meets scientific and ethical standards and that findings are rigorously analysed and thoroughly reported. The person conducting the research must have experience in focus group methodology, and in qualitative data analysis. He or she should also have knowledge in gerontology' (WHO, 2006, p. 4). Second, the collaboration of researchers and university with local city teams or services dedicated to the promotion and implementation of an 'Age-friendly' agenda is regularly underlined (Buffel et al., 2014; Garon, Paris, Beaulieu, Veil, \& Laliberté, 2014; Plouffe, 2011). Finally, the Second International Conference on Age-Friendly Cities in Quebec (September 9-11, 2013) that gathered more than 700 participants, from almost 50 countries, is particularly instructive to 
observe who is concerned: next to the $24 \%$ of researchers, $27 \%$ were members of community organizations, $33 \%$ were representatives and employees of cities and local councils, and $15 \%$ were older people. If researchers have been active communicators, none of them precisely communicates about their role and place in an AFE.

From these three illustrations, it appears that even if the Protocol of Vancouver served as an original driver for the actual WHO GNAFCC worldwide, even if research teams from Canada, the US or the UK are particularly involved in AFE, and even if the vibrant Conference of Quebec in 2013 brought participants from various backgrounds, the place and role of the researcher since the rising interest for AFE worldwide have almost never been discussed.

Our hypothesis is that such an observation contains lessons for AFE developments because a diversity of relations between researchers and stakeholders potentially exists (older people, city councils, local/central governments, NGOs, private sector, etc.). Furthermore, as ageing studies are concerned, one can consider some definitions of 'critical gerontology', presented as a theory with a social change horizon (Bernard \& Scharf, 2007; Moody, 1988), as an 'emancipatory knowledge' (Dannefer et al., 2008) fuelled by the Aristotelian preference of praxis on theory.

If the researcher has been originally considered as a technical support to deal with the implementation of focus groups, interviews, data analysis and report of findings (WHO, 2006), is it the only possible role a researcher can play? What does it mean to collaborate with local actors and stakeholders? Or, referring to the AFC Conference of Quebec, how can it be interpreted that researchers only represented a quarter of the attendance? 
Asking questions brings the answer and the argument of the article: the role of the researcher in AFCs and, more broadly in AFE development, may differ from a technician one; the role of the researcher in local development can be discussed; the specificity of the AFC Conference reveals a certain vision of science and, as a consequence, of relations between the researcher and what he or she studies.

In order to discuss the place and role of the researcher in AFE, as the core element of this article, we debate on the role of science in society through the place of the researcher in social sciences. This is operated by a special interest for discussion of 'public sociology' as a means of critically addressing applied issues and social problems (Burawoy, 2005). If public sociology has already been applied to social gerontology (Putney et al., 2005), here we show how it can be applied to the social issue of AFE development. Empirical data from an international comparison between AFCs in Quebec, Canada and in Wallonia, Belgium is presented. Final discussion addresses the potential of a 'public' and praxis oriented science of AFE through larger audience target (or 'action in knowledge') and through a seminal question for academic facing programmes such as AFE (as 'knowledge in action'). The tension between 'knowledge in action;' and 'action in knowledge' is explored in our concluding section, which draw on our two case studies.

\section{A debate applied in a new domain}

In order to explore the relationship between the applied researcher and a critical issue such as the development of age-friendly environments, we wish to dwell a little longer on distinctions, arising from sociology, but which have relevance to the wider application of 
social issues and of social work research. These include: public, professional, policy and critical dimensions to social inquiry. The debate about the role of the researcher in society and its relations to policy is a continuous discussion in social sciences since the Max Weber's lessons of 1919 on Science as a vocation and Politics as a vocation (Weber, 2004) until the call for 'public sociology' (Burawoy, 2005) and its reception by social scientists (Clawson et al., 2007). Further, a 'Political sociology' debate will help clarify potential positions for the researcher in order to face AFE. This public sociology is described as a dialogic relation between a social researcher and the public in which the agenda of each is brought to the table, in which each adjusts to the other (Burawoy, 2005, p. 9). This approach can be contrasted to professional sociology that he defines as social inquiry:

that supplies true and tested methods, accumulated bodies of knowledge, orienting questions, and conceptual frameworks. Professional sociology is not the enemy of policy and public sociology but the sine qua non [condition] of their existence providing both legitimacy and expertise for policy and public sociology. Professional sociology consists first and foremost of multiple intersecting research programs, each with their assumptions, exemplars, defining questions, conceptual apparatuses, and evolving theories. (Burawoy, 2005, p. 10)

While public sociology is a dialog with the public, policy sociology evidences the pragmatic/applied side of social science. Indeed,

Policy sociology is sociology in the service of a goal defined by a client. Policy sociology's raison d'être is to provide solutions to problems that are presented to us, 
or to legitimate solutions that have already been reached. Some clients specify the task of the sociologist with a narrow contract whereas other clients are more like patrons defining broad policy agendas. (Burawoy, 2005, p.9)

While public sociology is considered by Burawoy as the 'conscience of policy sociology', a last case plays the role of critical sociology. Critical sociology has the objective

to examine the foundations - both the explicit and the implicit, both normative and descriptive - of the research programs of professional sociology. (...) Critical sociology attempts to make professional sociology aware of its biases, silences, promoting new research programs built on alternative foundations. Critical sociology is the conscience of professional sociology just as public sociology is the conscience of policy sociology. (Burawoy, 2005, p. 10)

Critical sociology brings two fundamental questions: " "Sociology for Whom?" Are we just talking to ourselves (an academic audience) or are we also addressing others (an extraacademic audience) and " "Sociology for What?" Should we be concerned with the ends of society or only with the means to reach those ends' (Burawoy, 2005, p. 10).

From his four types of sociology, Burawoy build a synthetic table about the production of knowledge.

Table 1 Elaborating the four types of sociological knowledge, in Burawoy, 2005, p. 16

\begin{tabular}{|l|l|l|l|}
\hline \multicolumn{2}{|l|}{} & Academic & Extra-academic \\
\hline Instrumental & & Type 1: Professional sociology & Type 2: Policy sociology \\
\hline \multirow{2}{*}{} & Knowledge & Theoretical/empirical & Concrete \\
\cline { 2 - 4 } & Truth & Correspondence & Pragmatic \\
\hline
\end{tabular}




\begin{tabular}{|c|c|c|c|}
\hline & Legitimacy & Scientific norms & Effectiveness \\
\hline & Accountability & Peers & Clients \\
\hline & Politics & Professional self-interest & Policy intervention \\
\hline & Pathology & Self-referentiality & Servility \\
\hline Reflexive & & Type 3: Critical sociology & Type 4: Public sociology \\
\hline & Knowledge & Foundational & Communicative \\
\hline & Truth & Normative & Consensus \\
\hline & Legitimacy & Moral vision & Relevance \\
\hline & Accountability & Critical intellectuals & Designated publics \\
\hline & Politics & Internal debate & Public dialogue \\
\hline & Pathology & Dogmatism & Faddishness \\
\hline
\end{tabular}

Such a table must be carefully handled. While it has a clear pedagogical and clarifying dimension, it should not be seen as closed boxes: the four cases are connected ('There can be neither policy nor public sociology without a professional sociology') and personal biographies of the researcher can be at the junction of different types of sociology, as explained by Burawoy and often discussed by other authors.

Originally built in sociology, such a scheme has been discussed in different fields. Interestingly enough, some social gerontologists considered their own field work as a practical case for a 'public' perspective. Nevertheless, they made a distinction between sociology and social gerontology.

In social gerontology, distinctions between professional, critical, policy and public domains are blurred, even as ideal types, particularly between policy and public. 
Perhaps this is because of social gerontology's multidisciplinary origins and its common vision of ameliorating the problems of old age. Often, the same scholars are responsible for conducting basic research and communicating that research to various publics. (Putney et al., 2005, p. 90)

Because we will further discuss the use of 'public sociology' within the context of AFE, it is worth quoting Putney and her colleagues. Indeed,

social gerontologists, perhaps because of their experience with applied scholarship and practice or their strong policy orientation with its focus on the art of the possible, are less likely to be moral crusaders. This may be because the broader field of gerontology, including social gerontology, is overwhelmingly scientific, which tends to dampen a critical activism or expressions of moral outrage. It may also be a matter of style. Working in a multidisciplinary field with multiple publics, social gerontologists have learned to negotiate, to be diplomatic. (Putney et al., 2005, p. 90)

After clarification of 'public sociology', and existing links with social gerontology, we can turn towards empirical data to explore the richness of such a perspective to analyse the role of the researcher into AFE development.

Case studies: comparing Walloon first steps with AFCs versus the long history of AFCs in Quebec

Inspired by Table 1, this section discusses the central role of the researcher in AFC development by exploring the potential meeting of policy and public sociology, plus, at a certain distance, with professional and critical concerns. While the search for a 'public sociology' is a key driver of AFC Quebec, the policy sociology (as the only knowledge and 
practice of AFC Wallonia available by the time this article was written) produces more limited results, even if many actors appear very motivated in Wallonia, especially older people representatives.

\section{The Walloon case study}

While Belgium has only one officially recognized AFC (Brussels: see Buffel, 2012), the Minister of Health of the Walloon region decided in 2012 to fund a one-year program (2.5 million€) for helping Walloon cities to be more 'Age-Friendly' conscious. A total of 172 projects have been submitted (out of 262 Walloon cities, meaning that a high level of cities, $65 \%$, show an interest in the theme) and 60 have been selected, for an average amount of $40000 €$ per project. The analysis of the Walloon programme has been presented in an internal report to the Health Administration (Moulaert \& Houioux, 2013). It has been based on a fieldwork of 12 of the 60 selected cities (with an amount of funding from 7750 to 80 $000 €$, depending on the size of population and the scope of the project introduced). In these 12 cities, we conducted 48 interviews with representatives of seniors, elected local politician or authority and members of city services. All of them have been involved in the city application of the programme. We also had access to the selection process of cities organized by the Health Administration and had informal meetings with government employees and a member of the cabinet of the Minister of Health in charge of the programme. From this research, two core elements summarize the Walloon case study and the visibility given to researchers.

1) The search for a 'pragmatic truth', the WHO as a distant source of inspiration. For those who are used to the AFC cycle (supposed to be five years), the one-year length of the 
Walloon programme seems to be an apparent contradiction. Indeed, the first three out of four steps of the WHO GNAFCC (planning, implementation, progress evaluation, continual improvement) have been mentioned in the call of the programme; 'pragmatically', the first three out of four phases of planning (involving older people, assessing age-friendliness, developing an action plan, identifying indicators) were similarly supposed to be included into the completed application form for cities. Little is common here with the systematic consultation of older people from the original perspective (WHO, 2007a). This may be attributed to the search of a 'pragmatic truth' by people (i.e. people who launched the programme) who considered AFCs as an attractive flagship but had poor or no resources and little contact with the AFC project or with any 'real' person in the WHO, in contrast with Canada or Quebec (Plouffe, 2011). Nevertheless, some consultations with older people and service providers have been conducted in some cities, even prior the call of the Minister. Based on enquiries led by the local consultative council for seniors in some cases, they often received the support of local authorities. This search of truth should also take into account what already existed in Wallonia: within the 12 cities surveyed, most obtained a good score in the selection process concerning 'social participation of older people'. This was due to the presence of the local consultative councils for seniors into the projects. In search of 'truth', we also note the recurrent 'Social Cohesion Plan', a plan co-financed by the central region and local authorities. If not specifically addressed to older people, such plan may produce data and actions concerning them through isolation or social exclusion studies.

Such a pragmatic search of truth is a consequence of a distance from the WHO program on AFCs. Nonetheless, this was not entirely absent. While the eight axes of the AFC framework (WHO, 2007a) have been mentioned in the 'methodological annex' provided by the region to 
the candidates to funding, only three out of 172 projects refer to this framework. In our interviews, only three out of 48 people mentioned it; the vast majority has never heard of it or considers it as "too far" from their local day-to-day routine. In summary, the WHO framework serves as an inspiration for the central governmental body (the Health Minister); no official contact has been made with the WHO and only one city officially planned to become a member of the WHO GNAFCC. However, if social participation is a cornerstone for AFCs, it was permitted and shaped by the inclusion of older people from local consultative councils for seniors into the project's application and during its development.

2) The absence of research since the beginning, the 'servility pathology'. The research and the researcher - has been quasi absent from this programme. Until now, neither funding nor mandate has been distributed to implement or organize a full AFC project. As researcher, we jump into the project as reviewer for the assessment phase of the 172 projects, due to scientific expertise in active ageing and AFC abroad. We consequently send information on the WHO programme and international network to the Ministry of Health staff and to the administration in charge of the programme. The projects have been financed to support activities improving social cohesion (support to local consultative councils for seniors; senior centre and intergenerational activities; seniors' activities programmes; computer and internet courses intended for older people, isolated or not, etc.), urban adaptations (installation of benches, fitness tools and paths, facilitated access to public buildings, etc.) and improvement of local information on ageing (via directory or information journal targeting seniors in multiple domains: pension, health, mobility, housing, culture, etc.). 
All in all, the role of the researcher has suffered here from 'servility' to public policy. Nevertheless, since the end of 'research', we received various demands from journalists to explain what AFC means (newspaper \& radio), for oral presentations in non-scientific conferences (first Walloon conference on health and care, April 2014) and in scientific conferences (the authors were keynote speakers at an international Conference in Liège, May 2014). There has been a particular interest from older people representatives themselves; they even asked to think about a training series on the subject. In doing so, the production of knowledge (see Table 1) enters into a broader public dialogue which can slightly transform 'policy intervention' into a more 'public sociology' perspective. It also shows that even if the Walloon region is not directly connected to the principles of AFCs/AFE, local actors and older people representatives already organize practices similar to what is promoted internationally through AFCs/AFEs. Such 'public dialogue' recalls the Second International Conference on Age-Friendly Cities in Quebec 2013, illustrated in introduction. This Conference was probably a typical element of the Quebec's development of AFCs since $2007-2008$.

\section{The Quebec case study}

In 2007, two researchers from Quebec, who had been part of the WHO research initiative that brought the AFC guide (WHO, 2007a) and checklist (WHO, 2007b), presented the result of their work to the public consultation on the living conditions of senior citizens in Quebec (a province of Canada). This consultation was held then by the new Quebec Seniors' minister who just arrived in office. The presentation was performed in a 10-minute speech to a very large audience (seniors' organizations, politicians, researchers, journalists, etc.) and received an enthusiastic response from the different participants and the panel of politicians and 
experts. It might have been the first public researcher act. Therefore, a couple of weeks later, the Secretariat, interested in the WHO's concept of AFCs, contacted the research team to develop collaboration. The initial mandate was actually much opened. The model developed was the complete initiative of the research team, which proposed a researchaction model, including a structured evaluation process (Garon, Beaulieu, Veil, Paris, \& Bigonnesse, 2012). Contrary to what happened in Walloon experience, a three-steps process is financed by Seniors' Secretariat of Québec. The goal was to implement the AFC-QC in seven pilot projects: five mid-sized municipalities (20 000 to 150000 inhabitants), one district of a large city and one remote regional county, which itself comprises 22 municipalities across a territory of 11970 miles (a density of 0.5 people by mile). In both the programming and research processes, the AFC-QC is based primarily on a participatory approach (Minkler, 2005). Often called a 'bottom-up' approach, it implies that people are in better positions to talk about their own situations and to help discern solutions to their problems, often more effectively than these predefined by experts who are detached from their reality (Greenhalgh et al., 2007). Moreover, the AFC-QC relies on a community-building approach, that is, a comprehensive process by which stakeholders of a local community gather together to act towards the improvement of the quality of life of older adults. Community building corresponds to actions that engage individuals and local organizations concerned by a situation they wish to transform by joining their forces. This approach refers to a different way of acting in the public policy framework and generates social ties (Chaskin et al., 2001).

Six years later, 700 Municipalities are involved in a three-stage process: 1 . social diagnosis with the participation of seniors, 2 . action plan that must be voted by the city council and 3 . 
implementation of those actions. A steering committee that includes seniors is also mandated during the two first stages.

Meanwhile, the research team has been financed throughout three new governments. Furthermore, they have been the organizers of the Second International Conference on AgeFriendly Cities in Quebec; next to its clear objective to address the issues of 'AgeFriendliness' to a variety of audience beyond peers (in order to avoid the 'self -referentiality' pathology of 'professional sociology', Table 1), the Conference was also a practical experience (praxis) of a large internationalization (more than 50 countries) of the AFC process. Such 'need for an "internationalization" of environmental gerontology' (Buffel, 2012 referring to Parmelee, 1998) to escape the US dominant production of knowledge is more than a theoretical position (Buffel, 2012). Let's isolate two core elements of the Quebec case study.

1) Québec's research team and the 'practice of a public sociology'. Like Monsieur Jourdain speaking prose all his life without knowing it, many researchers are doing public sociology, according to Burawoy! It is certainly the case when they stand on a community building approach. In doing so, knowledge as a main category for understanding a reality can't be only a question of adequacy or discrepancy with a theoretical framework. It is even more relevant when they are striking to change this reality. Therefore, the knowledge category must result from an exercise that enhances the possibilities of creating common grounds, common experiences. This might happened to people involved in the steering committee, which is a central element in Quebec for the implementation of an Age-Friendly Community. Is there any consensus that can only be built around rhetorical exchanges? This might be an academic mode but not the one that takes in a process of community building that occurs on 
an AFC field. Therefore, the work of researchers in this process is to help shaping possible consensus. On some actual issues, for example environmental ones, it's rather difficult as the levels of action are not necessarily locally based. That situation constrains the different stakeholders to work together for the common good of all. This includes the private and public spheres (from their own family to the social and built environments). This might be an explanation of the 'faddishness' of the AFC programme in Quebec. Nevertheless, the legitimacy of the research team's work is to be found in the accuracy of the findings and the relevance of the knowledge transfer section of its research programme.

2) The 'knowledge transfer' as an ongoing public open dialogue. From the beginning of its mandate, the research team underlined the importance of knowledge transfer activities. Starting with training activities with all members of the steering committee of the seven pilot-projects to adapt the three-step model, the research team started to receive specific questions on different domains. These questions aimed to help the different stakeholders to make the best choice for their plan of actions. We didn't propose any kind of seminar or meetings between the pilot-projects but we finally organised four seminars on various themes (housing, social participation, etc.) that were suggested by the participants. After less than three years, the programme is still popular and we were asked by the Seniors' Secretariat to participate as advisors with the group of the ten major cities of the province (cities with more than 100000 inhabitants). This group counts for more than $50 \%$ of the Quebec's population. We performed six training sessions on various aspects of the model. For instance, what kind of public consultations are accurate, how it can be adapted? And how to deal with the process of evaluation? We trained the consultant who was in charge of implementing the programme in Montreal. One of the most important tools of our 
knowledge transfer platform is probably the website. It started with the idea of helping the seven pilot-projects to network, but it's now used by nearly 8000 people in more than 30 countries... even if the website is still mainly in French! Since April 2014, all practical tools are now free and publicly accessible. The intranet has been removed since. An important knowledge transfer is thus the main guide to implement an AFC initiative in Quebec. The results of research have been converted into a comprehensive and user-friendly guide that has been downloaded more than 2000 times since July 2013. While there are great differences between seniors' organizations, public servants or political stakeholders, they are all essential to the process of becoming an Age-Friendly Community: the knowledge transfer activities target all these people.

However, "knowledge transfer" is bringing new challenges. For instance, if the research team produces the knowledge and transfers it through the website or by providing trainings to the trainers who are going to work directly with the city, the larger dissemination in the 700 municipalities is commissioned to the "Carrefour Action Famille Municipalité" (CAMF). This non-profit organization originated from family policies, which has for consequence that the new "knowledge transfer" seems to be trapped by their focus in family matters. As we know seniors aren't only grand-parents!

Nevertheless, from the academic sociology point of view, the research team has simultaneously performed by welcoming into its rank five master students (gerontology and social work) and two Ph.D. (gerontology and science of education) students. About 70 conferences for public and scientific audiences in more than ten countries have been given since 2009. For the same period of time, we published 25 articles in various journals in three languages (mainly in French, then in English and finally in Portuguese). Moreover, in 
spring 2014, our research team was granted for a research project from the prestigious Canadian Institutes for Health Research (CIHR). Professional sociology position is also an instrument to explore methodological dilemmas: for instance, if knowledge transfer comes with programme evaluation, how can we propose methodologies that allow the meeting of different logics (managerial and economic one for the funding partners; community-driven for older people)? And is this simply possible? Or is it a paradigmatic dead-end?

\section{Conclusion: a twofold praxis of AFE}

This article has proposed a self-reflexive work about the place and role of the researcher within the AFE development. If sociology has been a good driver by introducing 'public sociology' (Burawoy, 2005) and if social gerontology regards itself as self-application of such perspective (Putney et al., 2005), we have shown that the AFE development can be illustrated as the search for a 'public sociology' (Quebec case) in dialog with 'policy sociology' (Walloon case), both of them having their own limits.

Moreover, can't we extent the result of our analysis to larger geographical contexts (by considering the general relations between researchers and policy makers)? This would coincide with praxis as 'knowledge in action' (dialog between types 2 and 4 of Table 1). And can't we extent the legitimacy of Burawoy's proposition (by confronting empirical data and knowledge of public/policy sociology with knowledge within critical/professional sociology) to include critical discourse on AFCs (Buffel et al., 2012) and explain how such position is needed to evolve towards pragmatism (Buffel et al., 2014). This would coincide with praxis as 'action in knowledge' (dialog between right and left columns of Table 1). Praxis as 'knowledge in action'. The extension of comparing Walloon and Quebec cases drives us 
toward the dialog between policy and public sociology. The road to public sociology, if not perfect (see the potential faddishness of any programme such as the AFE), has at least one lesson that can be addressed to the (many) application (s) of AFE focusing mainly on policy initiative and policy sociology: if needed at the beginning of the project, relation to policy makers (as clients) and to different stakeholders (here we would particularly point older people representatives) shouldn't be the end of the game. Even if the researcher has rarely the opportunity to influence these clients (in democracy, policy makers can quickly change), he must be conscious that the final target is the public at large. Older people indeed, but even adults. Also, the researcher in contact with such clients should not forget his relations with professional and critical sociology.

Praxis as 'action in knowledge'. As the Quebec case expressed, is there any consensus that can only be built around rhetorical exchanges? This might be an academic mode but not the one that takes in a process of community building that occurs on an AFC field. For professional and critical gerontologists, one has seen that consensus was replaced by correspondence or normativity.

Indeed, correspondence is necessary for professional knowledge as it can produce new avenues for research, new subfields such as 'environmental gerontology' (Phillipson, 2004). While the accountability of such professional perspective is oriented towards peers, one observe the recurrence of these themes in ageing handbooks (Phillipson, 2010, 2011).

Following Burawoy, professional and critical sociology are self-dependent (the latter being the conscious of the first one) in the same vein as policy and public sociology (this being expressed before). However, could a critical perspective on AFE be only accountable to 
critical intellectual and a professional perspective accountable to peers? More precisely, can't we defend the need for a dialog between the four types of perspectives? Behind AFE case-study, can we produce knowledge only with notions and concepts and poor data? Let's take a final look at the long history of AFE/AFCs.

Clearly, at its origins, the AFC initiative might be considered as a service for the WHO; the client wanted to produce a public tool: a checklist (WHO, 2007b) for cities to verify/indicate if they meet the challenges of ageing (WHO, 2007a). Given the central place of the checklist and its target of providing a 'universal standard for an age-friendly city' (WHO, 2007a, p. 11), some critical authors (Buffel et al., 2012) consequently identified the WHO initiative (WHO, 2007a) as the 'ideal' city, as other models identified by others (Lui et al., 2009). 'However, against what might be called the "idealistic model", a focus on the material conditions of city life may be a better starting point for understanding pressures on the lives of older people.' (Buffel et al., 2012, p. 602) If such criticism is fruitful and correct, it nevertheless ignores one point: whether, outside the head of researchers, the WHO checklist has been used in the mentioned direction. In fact, one may argue that the checklist was not seen as prescriptive but mostly descriptive. It was aimed to give an idea of how a city could be more age-friendly; as any programme, its understanding should always be empirically based. Interestingly enough, this research team continues to produce very high quality knowledge. Most interestingly, their knowledge was not driven by a theoretical perspective anymore but has taken a stronger empirical base (Buffel et al., 2014). A radical change of the titles expresses the new perspective. The 2012 title 'Ageing in urban environments: Developing "agefriendly" cities' shows a preference for theory over practices. The 2014 title 'Developing Age- 
Friendly Cities: Case Studies From Brussels and Manchester and Implications for Policy and Practice' , however, gives priority to empirical data.

In doing so, one can revisit the description of the WHO's programme as the 'ideal city' (Buffel et al., 2012) by giving priority to empirical data (Buffel et al., 2014). More precisely, we suggest that it was only the first steps of a dialogic communication between older people, city officers, local and central policy makers... and researchers!

\section{Acknowledgments}

This work was supported by the Wallonie-Bruxelles International Agency (WBI), under Grant SUB/2014/160138 for the Belgian case and by the Secrétariat aux Aînés for the Quebec case.

\section{References}

Bernard, M., \& Scharf, T. (2007). Critical perspectives on ageing societies. Bristol: Policy Press.

Buffel, T. (2012). Experiences of place and neighbourhood in later life: Developing agefriendly communities. Brussels: Vrij Universiteit Brussel.

Buffel, T., McGarry, P., Phillipson, C., De Donder, L., Dury, S., De Witte, N., ... Verté, D. (2014). Developing Age-Friendly Cities: Case Studies From Brussels and Manchester and Implications for Policy and Practice. Journal of Aging \&amp; Social Policy, 26(1-2), 5272. 
Buffel, T., Phillipson, C., \& Scharf, T. (2012). Ageing in urban environments : Developing "agefriendly" cities. Critical Social Policy, 32(4), 597-617.

Burawoy, M. (2005). For public sociology. American Sociological Review, 70(2), 4-28.

Chaskin, R., Brown, P., Venkatesh, S., \& Vidal, A. (2001). Building Community Capacity. New York: Aldine de Gruyter.

Clawson, D., Zussman, R., Misra, J., Gerstel, N., Stokes, R., Anderton, D. L., \& Burawoy, M. (Eds.). (2007). Public Sociology: Fifteen eminent sociologists debate politics and the profession in the twenty-first century. Berkeley: University of California Press.

Dannefer, D., Stein, P., Siders, R., \& Shura Patterson, R. (2008). Is that all there is? The concept of care and the dialectic of critique. Journal of Aging Studies, 22, 101-108.

Garon, S., Beaulieu, M., Veil, A., Paris, M., \& Bigonnesse, C. (2012). L'expérience québécoise du programme Villes amies des aînés de l’OMS : I'implantation dans sept projets pilotes. In J.-P. Viriot-Durandal, C. Pihet, \& P.-M. Chapon (Eds.), Les défis territoriaux face au vieillissement (pp. 69-88). Paris: La Documentation française.

Garon, S., Paris, M., Beaulieu, M., Veil, A., \& Laliberté, A. (2014). Collaborative Partnership in Age-Friendly Cities: Two Case Studies From Quebec, Canada. Journal of Aging \& Social Policy, 26(1-2), 73-87.

Greenhalgh, T., Kristjansson, E., \& Robinson, V. (2007). Realist review to understand the efficacy of school feeding programmes. BMJ, 335(7625), 858-861.

Lui, C.-W., Everingham, J.-A., Warburton, J., Cuthill, M., \& Bartlett, H. (2009). What makes a community age-friendly: A review of international literature. Australasian Journal on Ageing, 28(3), 116-121.

Menec, V. H., Means, R., Keating, N., Parkhurst, G., \& Eales, J. (2011). Conceptualizing AgeFriendly Communities. Canadian Journal on Aging, 30(3), 479-493. 
Minkler, M. (Ed.). (2005). Community organizing and community building for health. New Brunswick, NJ: Rutgers University Press.

Moody, H. R. (1988). Toward a Critical Gerontology: The Contribution of the Humanities to Theories of Aging. In J. E. Birren, V. L. Bengtson, \& E. D. Deutchman (Eds.), Emergent Theories of Aging (pp. 19-40). New York: Springer.

Moulaert, T., \& Houioux, G. (2013). Les projets 'villes-amies des ainés' wallons en pratique. 'Pour et par les aînés'. Enjeux de la participation sociale et du politique. Rapport de recherche final. Ministre de la Santé, de l'Action sociale et de l'Égalité des Chances. Parmelee, P. A. (1998). Theory and research on housing for the elderly: The legacy of Kurt Lewin. In R. J. Scheidt \& P. G. Windley (Eds.), Environment and Aging Theory: A Focus on Housing (pp. 161-185). Westport, CT: Greenwood Press.

Phillipson, C. (2004). Urbanisation and ageing: towards a new environmental gerontology. Ageing and Society, 24, 963-972.

Phillipson, C. (2010). Ageing and Urban Society: Growing Old in the "Century of the City." In C. Phillipson \& D. Dannefer (Eds.), The Sage Handbook of Social Gerontology (pp. 597-606). Thousand Oaks: Sage.

Phillipson, C. (2011). Developing Age-Friendly Communities: New Approaches to Growing Old in Urban Environments. In S. Settersten \& J. Angel (Eds.), Handbook of Sociology of Aging (pp. 279-293). New York: Springer.

Plouffe, L. (2011). Villes amies des aînés : de ses origines à son déploiement international. Vie et Vieillissement, 9(1), 14-18.

Putney, N. M., Alley, D. E., \& Bengtson, V. L. (2005). Social gerontology as public sociology in action. The American Sociologist, (Fall/Winter), 88-104. 
Weber, M. (2004). The vocation lectures. (D., Strong, Tracy B Owen, Trans.). Indianapolis: Hackett.

WHO. (2002). Active ageing. A policy framework World Health Organization to the Second United Nations World Assembly on Ageing. Madrid: WHO.

WHO. (2006). Vancouver Protocol. WHO.

WHO. (2007a). Global Age-friendly Cities: A Guide. Geneva: WHO.

WHO. (2007b). Checklist of Essential Features of Age-Friendly Cities. Geneva: WHO. 